\title{
Non contiguous-finished genome sequence and description of Cellulomonas massiliensis sp. nov.
}

\author{
Jean-Christophe Lagier ${ }^{1}$, Dhamodharan Ramasamy ${ }^{1}$, Romain Rivet $^{1}$, Didier Raoult ${ }^{1}$ and \\ Pierre-Edouard Fournier ${ }^{1 *}$
}

${ }^{1}$ Aix-Marseille Université, Faculté de médecine, Marseille, France

*Corresponding author: Pierre-Edouard Fournier (pierre-edouard.fournier@univmed.fr)

Keywords: Cellulomonas massiliensis, genome

Cellulomonas massiliensis strain $\mathrm{JC}^{\mathrm{C}} 25^{\mathrm{T}} \mathrm{sp}$. nov. is the type strain of Cellulomonas massiliensis sp., a new species within the genus Cellulomonas. This strain, whose genome is described here, was isolated from the fecal flora of a healthy Senegalese patient. C. massiliensis is an aerobic rod-shaped bacterium. Here we describe the features of this organism, together with the complete genome sequence and annotation. The 3,407,283 bp long genome contains 3,083 protein-coding and 48 RNA genes.

\section{Introduction}

Cellulomonas massiliensis strain JC225T (= CSUR $\mathrm{P} 160=$ DSM 25695) is the type strain of $C$. massiliensis sp. nov. This bacterium is a motile, Gram-positive, aerobic, indole-negative rod that was isolated from the stool of a healthy Senegalese patient as part of a culturomics study aiming at cultivating all bacterial species within human feces [1].

The current approach to the classification of prokaryotes, known as polyphasic taxonomy, relies on a combination of phenotypic and genotypic characteristics [2]. However, as more than 3,000 bacterial genomes have been sequenced [3], and proteomic information is more becoming more readily accessible [4], we recently proposed that genomic information should be integrated in the description of new bacterial species [5-11].

The genus Cellulomonas was created in 1923 to reclassify several bacteria previously classified as Bacillus species [12]. To date, this genus is made of 19 species [13-24]. The two species that are the most phylogenetically related to $C$. massiliensis are C. composti [17] and C. persica [21]. Most of these species were originally solated from environmental samples, notably from habitats enriched in cellulose, such as soil or sugar fields, and occasionally from the rumen and activated sludge. Rare cases of human endocarditis [25], osteomyelitis [25], endophtalmitis [26] and cholecystitis [27] caused by Cellulomonas species have been reported. To date, members of the genus Cellulomonas have not been described in the normal fecal flora.

Here we present a summary classification and a set of features for $C$. massiliensis sp. nov. strain JC225 $25^{\mathrm{T}}$ together with the description of the complete genomic sequencing and annotation. These characteristics support the circumscription of the species $C$. massiliensis.

\section{Classification and features}

A stool sample was collected from a healthy 16year-old male Senegalese volunteer patient living in Dielmo (a rural village in the Guinean-Sudanian zone in Senegal), who was included in a research protocol. Written assent was obtained from this individual; no written consent was needed from his guardians for this study because he was older than 15 years old (in accordance with the previous project approved by the Ministry of Health of Senegal and the assembled village population and as published elsewhere [28].

Both this study and the assent procedure were approved by the National Ethics Committee of Senegal (CNERS) and the Ethics Committee of the Institut Fédératif de Recherche IFR48, Faculty of Medicine, Marseille, France (agreement numbers 09-022 and 11-017). Several other new bacterial species were isolated from this specimen using various culture conditions, including the recently described Anaerococcus senegalensis, Bacillus 
timonensis, Alistipes senegalensis, Alistipes timonensis,Clostridium senegalense, Paenibacillus senegalensis and Peptoniphilus timonensis [5-11], thus suggesting that the human digestive flora is far from being fully known. The fecal specimen was preserved at $-80^{\circ} \mathrm{C}$ after collection and sent to Marseille. Strain JC225 (Table 1) was isolated in May 2011 by passive filtration of the stool and aerobic incubation on Brain Heart Infusion agar at $37^{\circ} \mathrm{C}$. This strain exhibited a nucleotide sequence similarity of $98.3 \%$ with Cellulomonas composti (Kang et al 2007), the phylogenetically closest validated Cellulomonas species (Figure 1) that was cultivated from cattle farm compost [17]. This value was lower than the $98.7 \%$ 16S rRNA gene sequence threshold recommended by Stackebrandt and Ebers to delineate a new species without carrying out DNA-DNA hybridization [39]. By comparison to the Genbank database [40] strain JC225 ${ }^{\mathrm{T}}$ also exhibited a nucleotide sequence similarity greater than $99.5 \%$ with Cellulomonas sp. strain 3335BRRJ isolated from clean room environments (Genbank accession number FJ200382). This bacterium is most likely classified within the same species as strain JC225 ${ }^{\mathrm{T}}$ (Figure 1).

Table 1. Classification and general features of Cellulomonas massiliensis strain JC225 ${ }^{\top}$

\begin{tabular}{|c|c|c|c|}
\hline MIGS ID & Property & Term & Evidence code $^{\mathrm{a}}$ \\
\hline & Current classification & Domain Bacteria & TAS [29] \\
\hline & & Phylum Actinobacteria & TAS [30] \\
\hline & & Class Actinobacteria & TAS [31] \\
\hline & & Order Actinomycetales & TAS [31-34] \\
\hline & & Family Cellulomonadaceae & TAS [31,34-37] \\
\hline & & Genus Cellulomonas & TAS $[12,32]$ \\
\hline & & Species Cellulomonas massiliensis & IDA \\
\hline & & Type strain JC225 $5^{\top}$ & IDA \\
\hline & Gram stain & positive & IDA \\
\hline & Cell shape & rod & IDA \\
\hline & Motility & positive & IDA \\
\hline & Sporulation & nonsporulating & IDA \\
\hline & Temperature range & mesophilic & IDA \\
\hline & Optimum temperature & $37^{\circ} \mathrm{C}$ & IDA \\
\hline MIGS-6.3 & Salinity & growth in $\mathrm{BHI}$ medium $+5 \% \mathrm{NaCl}$ & IDA \\
\hline \multirow[t]{3}{*}{ MIGS-22 } & Oxygen requirement & aerobic & IDA \\
\hline & Carbon source & galactose & NAS \\
\hline & Energy source & chemoorganotrophic & NAS \\
\hline MIGS-6 & Habitat & human gut & IDA \\
\hline \multirow[t]{3}{*}{ MIGS-15 } & Biotic relationship & free living & IDA \\
\hline & Pathogenicity & unknown & NAS \\
\hline & Biosafety level & 2 & \\
\hline MIGS-14 & Isolation & human feces & \\
\hline MIGS-4 & Geographic location & Senegal & IDA \\
\hline MIGS-5 & Sample collection time & September 2010 & IDA \\
\hline MIGS-4.1 & Latitude & 13.7167 & IDA \\
\hline MIGS-4.1 & Longitude & -16.4167 & IDA \\
\hline MIGS-4.3 & Depth & surface & IDA \\
\hline MIGS-4.4 & Altitude & $51 \mathrm{~m}$ above sea level & IDA \\
\hline
\end{tabular}

Evidence codes - IDA: Inferred from Direct Assay; TAS: Traceable Author Statement (i.e., a direct report exists in the literature); NAS: Non-traceable Author Statement (i.e., not directly observed for the living, isolated sample, but based on a generally accepted property for the species, or anecdotal evidence). These evidence codes are from the Gene Ontology project [38]. If the evidence is IDA, then the property was directly observed for a live isolate by one of the authors or an expert mentioned in the acknowledgements. 


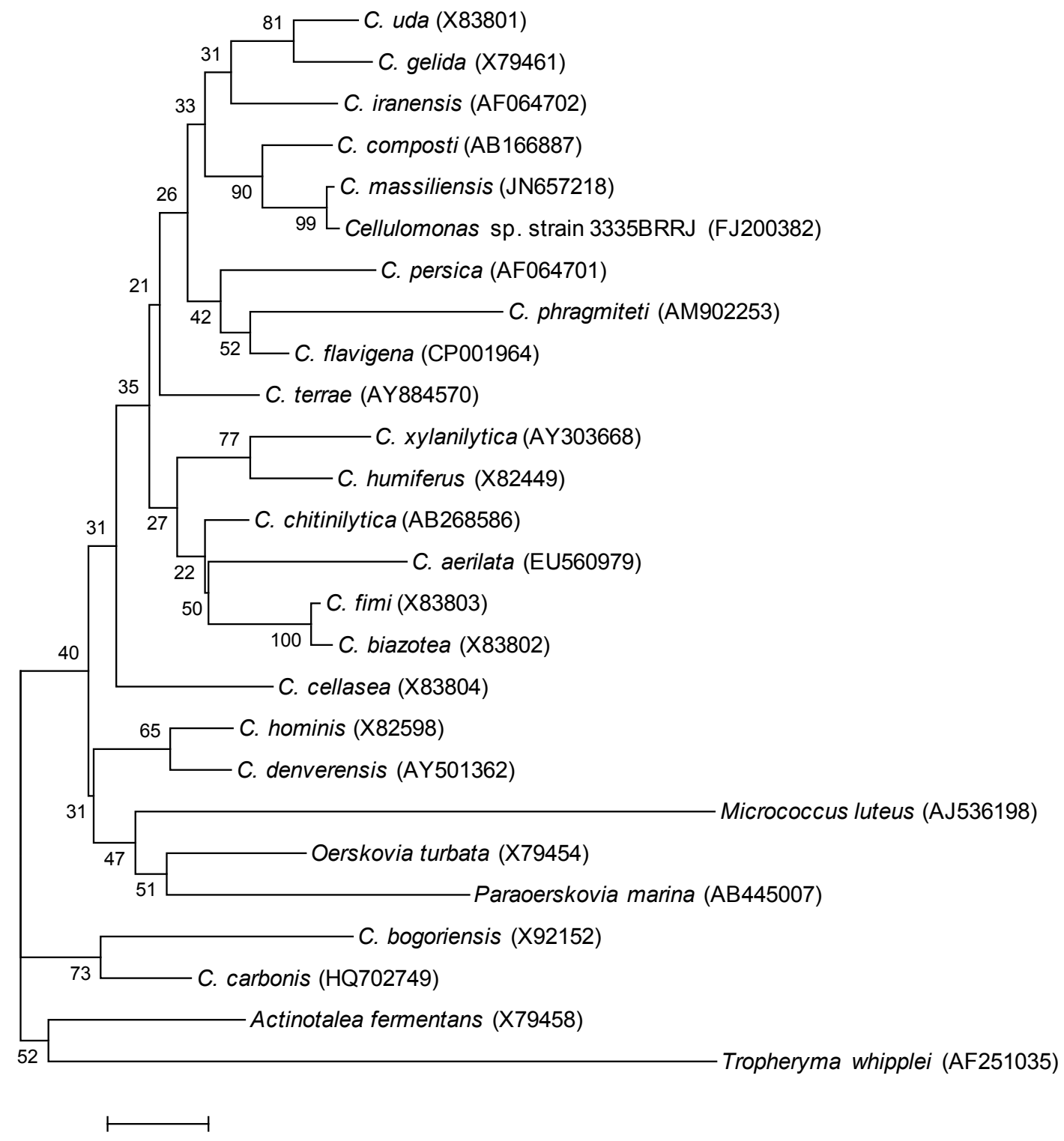

Figure 1. Phylogenetic tree highlighting the position of Cellulomonas massiliensis strain JC225 relative to other type strains within the genus Cellulomonas and other members of the family Cellulomonadaceae. GenBank accession numbers are indicated in parentheses. Sequences were aligned using CLUSTALW, and phylogenetic inferences obtained using the maximum-likelihood method within the MEGA software. Numbers at the nodes are bootstrap values obtained by repeating the analysis 500 times to generate a majority consensus tree. The scale bar indicates a $1 \%$ nucleotide sequence divergence.

Different growth temperatures $\left(25,30,37,45^{\circ} \mathrm{C}\right)$ were tested; no growth occurred at $25^{\circ} \mathrm{C}$ or $45^{\circ} \mathrm{C}$, growth occurred between 30 and $37^{\circ} \mathrm{C}$, and optimal growth was observed at $37^{\circ} \mathrm{C}$. Colonies were transparent and smooth with a diameter of $1 \mathrm{~mm}$ on blood-enriched Columbia agar and Brain Heart Infusion (BHI) agar. Growth of the strain was tested under anaerobic and microaerophilic conditions using GENbag anaer and GENbag microaer systems, respectively (BioMérieux), and in the presence of air, with or without $5 \% \mathrm{CO}_{2}$. Optimal growth was achieved aerobically. Weak growth was observed under microaerophilic condition and with $5 \% \mathrm{CO}_{2}$. No growth was observed under anaerobic conditions. Gram staining showed Gram-positive rods. A motility test was positive. Cells grown on agar are Gram-positive (Figure 2), with a diameter and length ranging from 0.37 to $0.60 \mu \mathrm{m}$ (mean, $0.48 \mu \mathrm{m}$ ), and from 0.55 to $1.4 \mu \mathrm{m}$ (mean, $0.95 \mu \mathrm{m}$ ), respectively, in electron microscopy, (Figure 3). 


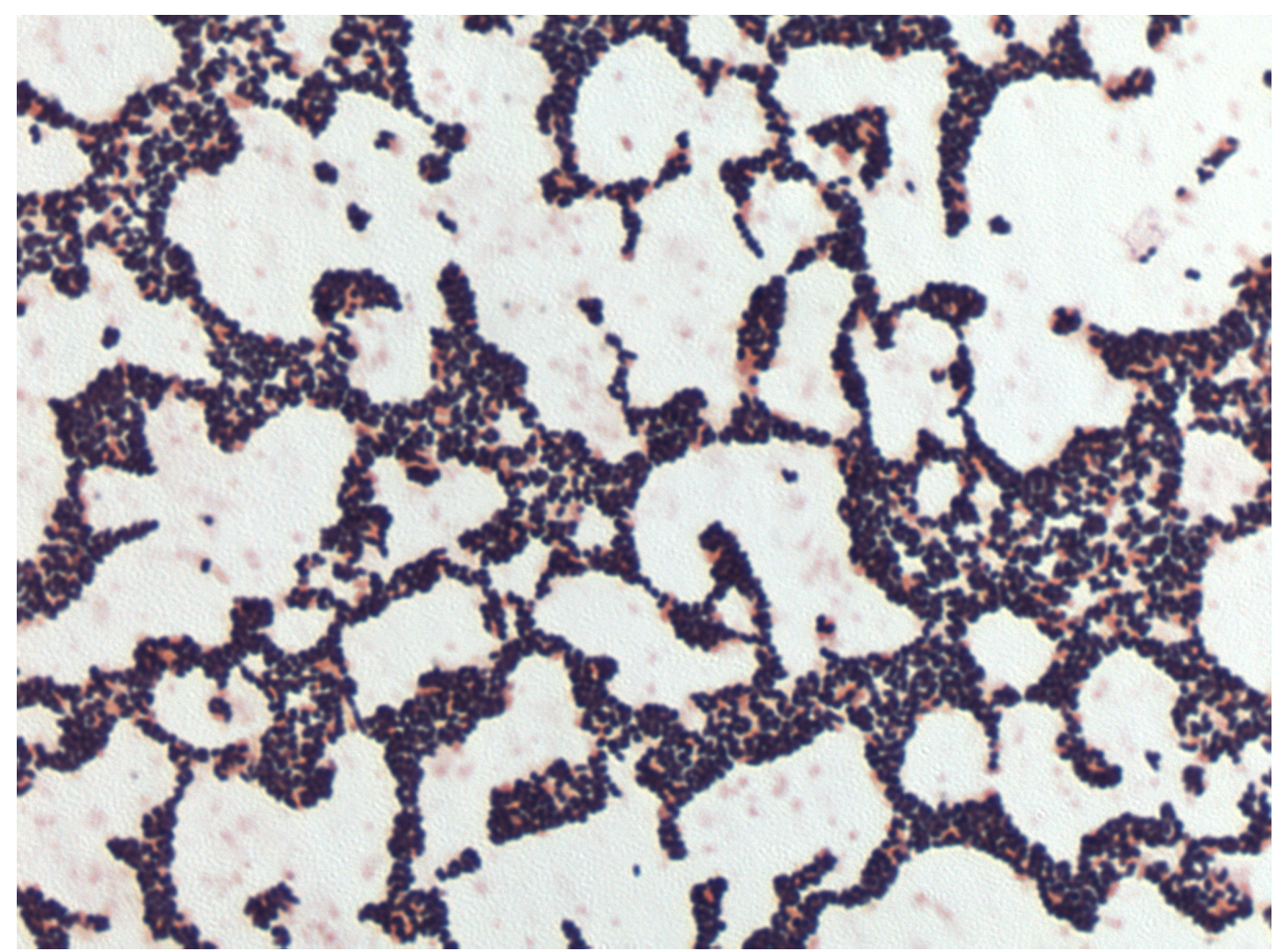

Figure 2. Gram staining of C. massiliensis strain JC225 ${ }^{\top}$

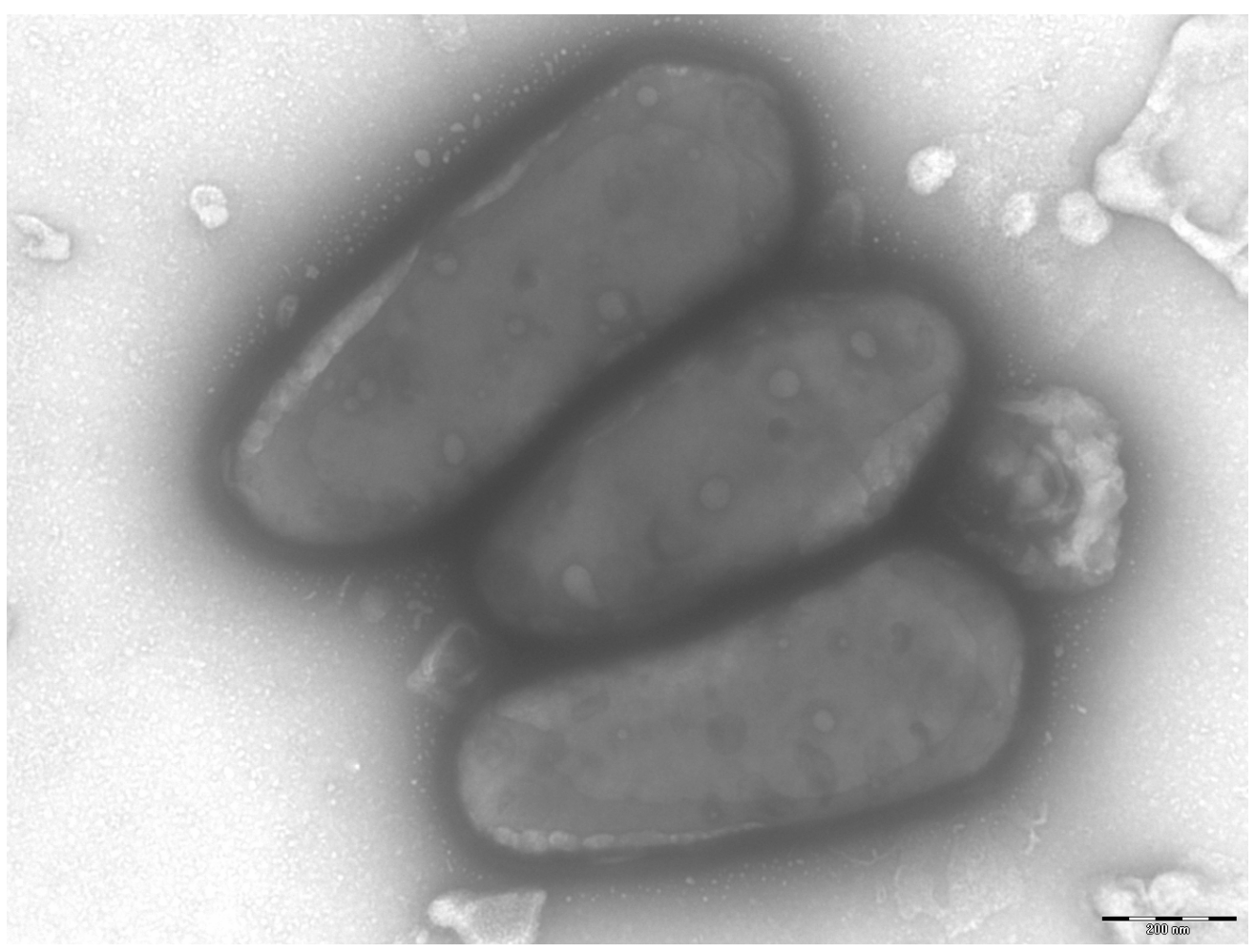

Figure 3. Transmission electron microscopy of C. massiliensis strain $\mathrm{JC}^{2} 25^{\top}$, using a Morgani 268D (Philips) at an operating voltage of $60 \mathrm{kV}$. The scale bar represents 200 $\mathrm{nm}$. 
Strain JC225 ${ }^{\mathrm{T}}$ exhibited catalase and oxidase activities. Using the API 20 NE system (BioMérieux), a positive reaction was obtained for aesculin hydrolysis and $\beta$-galactosidase. Negative reactions were obtained for nitrate reduction, indole production, glucose fermentation, arginine dihydrolase, urease, gelatin hydrolysis, and glucose, arabinose, mannose, mannitol N-acetylglucosamine, maltose, gluconate, caprate, adipate, malate, citrate, and phenyl-acetate assimilation. $C$. massiliensis is susceptible to amoxicillin, imipenem, gentamicin, and ciprofloxacin but resistant to trimethoprim/sulfamethoxazole and metronidazole. By comparison to C. composti [17], C. massiliensis differed in motility, nitrate reduction, gelatine hydrolysis, carbohydrate assimilation, and catalase activity (Table 2 ).

Table 2. Differential phenotypic characteristics of five Cellulomonas strains ${ }^{\dagger}$.

\begin{tabular}{|c|c|c|c|c|c|}
\hline Properties & 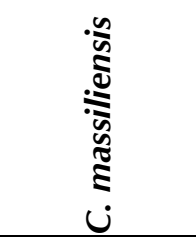 & 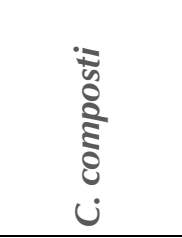 & ن & 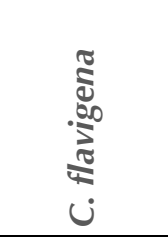 & 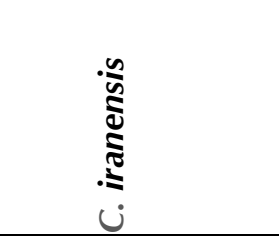 \\
\hline Oxygen requirement & aerobic & $\begin{array}{c}\text { Facultative } \\
\text { anaerobic }\end{array}$ & aerobic & aerobic & aerobic \\
\hline Gram astin & + & + & + & + & + \\
\hline Motility & + & - & + & - & + \\
\hline \multicolumn{6}{|l|}{ Production of } \\
\hline Catalase & + & - & na & + & na \\
\hline Nitrate reductase & - & + & + & + & + \\
\hline Urease & - & - & + & - & + \\
\hline Bgalactosidase & + & na & na & na & na \\
\hline $\mathrm{N}$-acetyl-glucosamine & - & na & na & na & na \\
\hline Arginine dihydrolase & - & na & na & na & na \\
\hline \multicolumn{6}{|l|}{ Fermentation for } \\
\hline Sucrose & - & + & na & + & na \\
\hline Glucose & - & + & na & + & na \\
\hline Mannitol & - & - & na & - & na \\
\hline Gluconate & - & - & na & W & na \\
\hline Maltose & - & + & na & + & na \\
\hline Hydrolysis of & & & & & + \\
\hline Gelatin & + & w & w & + & w \\
\hline Esculin & - & + & na & + & na \\
\hline $\mathrm{G}+\mathrm{C}$ content $(\mathrm{mol} \%)$ & 71.2 & 73.7 & na & $72.7-74.8$ & na \\
\hline Habitat & Human gut & Compost & Forest humus soil & Soil & Forest humus soil \\
\hline
\end{tabular}

${ }^{\dagger}$ Cellulomonas massiliensis strain JC225 $5^{\mathrm{T}}$, Cellulomonas composti strain TR7-06 ${ }^{\mathrm{T}}$, Cellulomonas persica strain I', Cellulomonas flavigena strain DSM $20109^{\mathrm{T}}$, and Cellulomonas iranensis strain $\mathrm{O}^{\mathrm{T}}$.

$\mathrm{na}=$ data not available; $\mathrm{w}=$ weak

na $=$ data not available; $w=$ weak 
Matrix-assisted laser-desorption/ionization timeof-flight (MALDI-TOF) MS protein analysis was carried out as previously described [5,41] using a Microflex spectrometer (Bruker Daltonics, Germany). Twelve distinct deposits were done for strain JC225 from 12 isolated colonies. The 12 JC225 spectra were imported into the MALDI BioTyper software (version 2.0, Bruker) and analyzed by standard pattern matching (with default parameter settings) against the main spectra of
3,769 bacteria, which were used as reference data in the BioTyper database. The database contained 11 spectra from 8 validly published Cellulomonas species, including Cellulomonas composti, the phylogenetically closest species to $C$. massiliensis. No significant score was obtained for strain $\mathrm{JC} 225^{\mathrm{T}}$, thus suggesting that our isolate was not a member of a known species within the Bruker database. We incremented our database with the reference spectrum from strain JC225T (Figure 4).

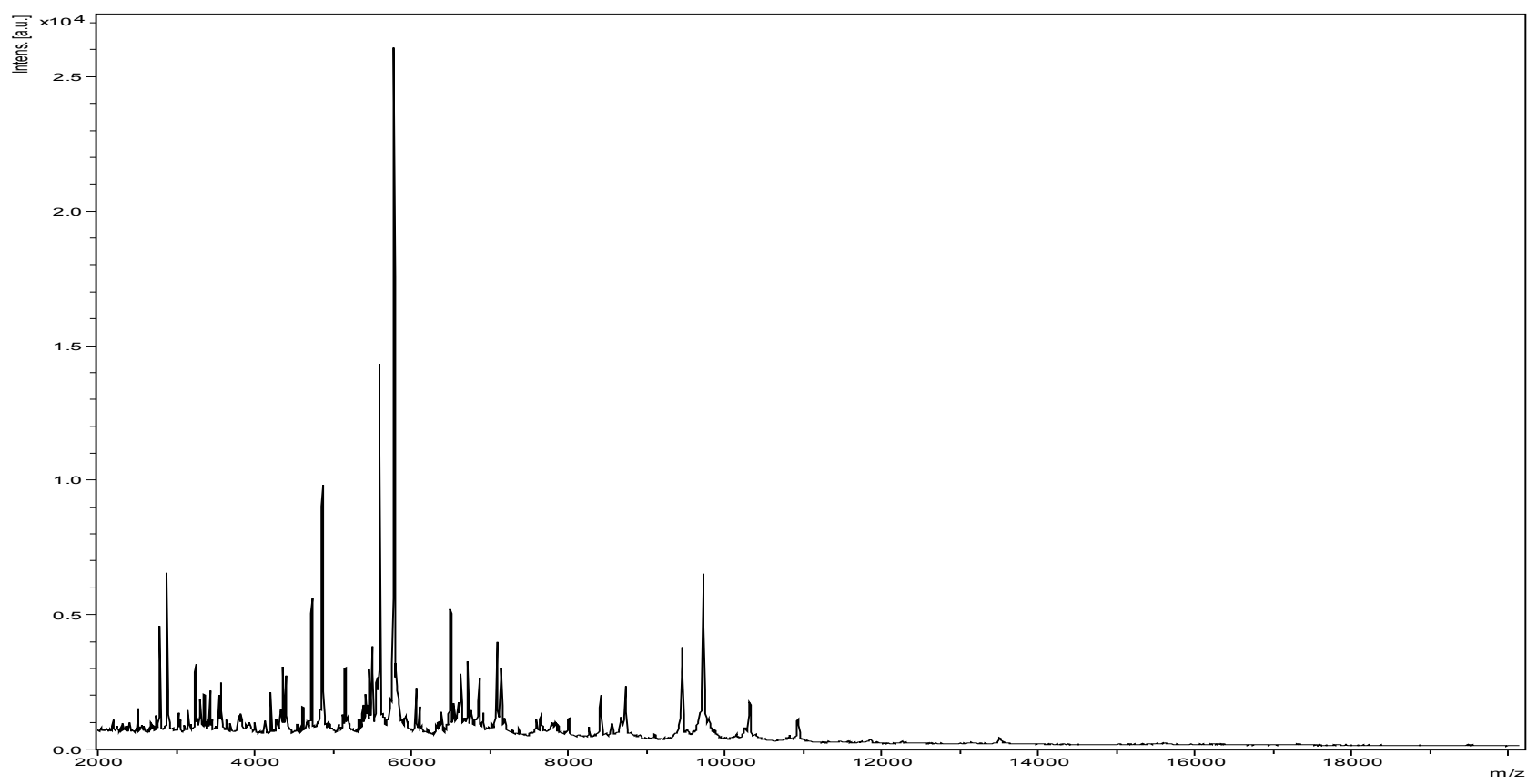

Figure 4: Reference mass spectrum from C. massiliensis strain JC225 ${ }^{\top}$. Spectra from 12 individual colonies were compared and a reference spectrum was generated.

\section{Genome sequencing information Genome project history}

The organism was selected for sequencing on the basis of its phenotypic differences, phylogenetic position and 16S rRNA similarity to other members of the genus Cellulomonas and is part of a study of the human digestive flora aiming at isolating all bacterial species within human feces. It was the fourth genome of a Cellulomonas species and the first genome of Cellulomonas massiliensis sp. nov. The EMBL accession number is CAHD00000000 and consists of 250 contigs ( $>=200 \mathrm{bp}$ ). Table 3 shows the project information and its association with MIGS version 2.0 compliance [42].

\section{Growth conditions and DNA isolation}

Cellumonas massiliensis sp. nov. JC225 ${ }^{\mathrm{T}}(=\mathrm{CSUR}$ $\mathrm{P} 160$ = DSM 25695) was grown aerobically on 5\% sheep blood-enriched Columbia agar (BioMérieux) at $37^{\circ} \mathrm{C}$. Ten petri dishes were spread and resuspended in $3 \times 100 \mu$ l of G2 buffer (EZ 1 DNA Tissue kit, Qiagen). A first mechanical lysis was performed using glass powder on a Fastprep-24 device (MP Biomedicals, Ilkirch, France) during $2 \times 20$ seconds. DNA was then treated with $2.5 \mu \mathrm{g} / \mu \mathrm{L}$ lysozyme $\left(30\right.$ minutes at $\left.37^{\circ} \mathrm{C}\right)$ and extracted using a BioRobot EZ 1 Advanced XL (Qiagen). The DNA was then concentrated and purified using a Qiamp kit (Qiagen). The yield and the concentration were measured using a Quant-it Picogreen kit (Invitrogen) on a Genios_Tecan fluorometer at $78.9 \mathrm{ng} / \mu \mathrm{l}$. 


\begin{tabular}{lll}
\multicolumn{2}{l}{ Table 3. Project information } & \\
\hline MIGS ID & Property & Term \\
\hline MIGS-31 & Finishing quality & High-quality draft \\
MIGS-28 & Libraries used & Paired-end 3 Kb library \\
MIGS-29 & Sequencing platforms & 454 GS FLX Titanium \\
MIGS-31.2 & Fold coverage & $25 \times$ \\
MIGS-30 & Assemblers & Newbler version 2.5.3 \\
MIGS-32 & Gene calling method & Prodigal \\
& EMBL ID & CAHD00000000 \\
& EMBL Date of Release & May 30, 2012 \\
& Project relevance & Study of the human gut microbiome \\
\hline
\end{tabular}

\section{Genome sequencing and assembly}

Both shotgun sequencing and paired-end sequencing strategies were used (Roche). Both libraries were pyrosequenced on a GS FLX Titanium sequencer (Roche). This project was loaded onto a single $1 / 4$ region of a PTP Picotiterplate (Roche, Meylan, France) for the shotgun library and $2 \times 1 / 4$ region for the 3-kb paired-end library. The shotgun library was constructed with 500ng of DNA with the GS Rapid library Prep kit as described by the manufacturer (Roche). For the paired-end library, $5 \mu \mathrm{g}$ of DNA was mechanically fragmented on a Hydroshear device (Digilab, Holliston, MA, USA) with an enrichment size at $3-4 \mathrm{~kb}$. The DNA fragmentation was visualized through an Agilent 2100 BioAnalyzer on a DNA labchip 7500 with an optimal size of $3.216 \mathrm{~kb}$. The library was constructed according to the 454 Titanium paired-end protocol (Roche). Circularization and nebulization were performed and generated a pattern with an optimum at $395 \mathrm{bp}$. After PCR amplification through 17 cycles followed by double size selection, the single stranded paired-end library was quantified on with a Quant-it Ribogreen kit (Invitrogen) on a Genios Tecan fluorometer at $132 \mathrm{pg} / \mu \mathrm{L}$. The library concentration equivalence was calculated at $6.11 \mathrm{E}+08$ molecules $/ \mu \mathrm{L}$. The libraries were stored at $-20^{\circ} \mathrm{C}$ until further use.

The shotgun library was clonally amplified with 3 cpb in 3 emPCR reactions and the 3-kb paired-end library was amplified with $0.5 \mathrm{cpb}$ in 4 emPCR reactions with the GS Titanium SV emPCR Kit (Lib-L) v2 (Roche). The yield of the shotgun emPCR reactions was $10.13 \%$, and the yields of the paired-end emPCRs was $8.6 \%$, in the range of 5 to $20 \%$ from the Roche procedure.

Approximately 790,000 beads for both the shotgun and paired-end libraries were loaded on the GS Titanium PicoTiterPlate PTP Kit $70 \times 75$ and sequenced with the GS FLX Titanium Sequencing Kit XLR70 (Roche). The runs were performed over- night and then analyzed on the cluster through the gsRunBrowser and Newbler Assembler (Roche). A total of 255,758 and 256,082 passed filter wells were obtained for the shotgun and paired-end strategies, respectively, and generated 86.75 and $78.45 \mathrm{Mb}$ of DNA sequence with length averages of 339 and $313 \mathrm{bp}$, respectively. The filter passed sequences were assembled using Newbler with $90 \%$ identity and $40 \mathrm{bp}$ as overlap. The final assembly identified 250 contigs ( $>200 \mathrm{bp}$ ) arranged into 5 scaffolds and generated a genome size of $3.40 \mathrm{Mb}$.

\section{Genome annotation}

Open Reading Frames (ORFs) were predicted using Prodigal [43] with default parameters but the predicted ORFs were excluded if they were spanned a sequencing GAP region. The predicted bacterial protein sequences were searched against the GenBank database [40] and the Clusters of Orthologous Groups (COG) databases using BLASTP. The tRNAscan-SE tool [44] was used to find tRNA genes, whereas ribosomal RNAs were found by using RNAmmer [45]. Transmembrane domains and signal peptides were predicted using TMHMM [46] and SignalP [47], respectively. ORFans were identified if their BLASTp $E$-value was lower than 1e-03 for alignment length greater than 80 amino acids. If alignment lengths were smaller than 80 amino acids, we used an $E$-value of 1e-05. Such parameter thresholds have been used in previous works to define ORFans. To estimate the mean level of nucleotide sequence similarity at the genome level between C. massiliensis and C. flavigena and C. fimi (EMBL accession numbers CP001964 and CP002666, respectively), the only two available genomes from validly published Cellulomonas species to date, we compared the ORFs only using BLASTN at a query coverage of $\geq 70 \%$ and a minimum nucleotide length of $100 \mathrm{bp}$. 


\section{Genome properties}

The genome is 3,407,283 bp long ( 1 chromosome, but no plasmid) with a $71.22 \% \mathrm{G}+\mathrm{C}$ content (Table 4 and Figure 5). It is composed of 5 scaffolds. Of the 3,131 predicted genes, 3,083 were proteincoding genes, and 48 were RNAs (1 rRNA operon and 45 tRNA genes). A total of 2,184 genes
(70.84\%) were assigned a putative function, and 256 genes were identified as ORFans (8.30\%). The remaining genes were annotated as hypothetical proteins. The distribution of genes into COGs functional categories is presented in Table 5 . The properties and the statistics of the genome are summarized in Table 4 and 5.

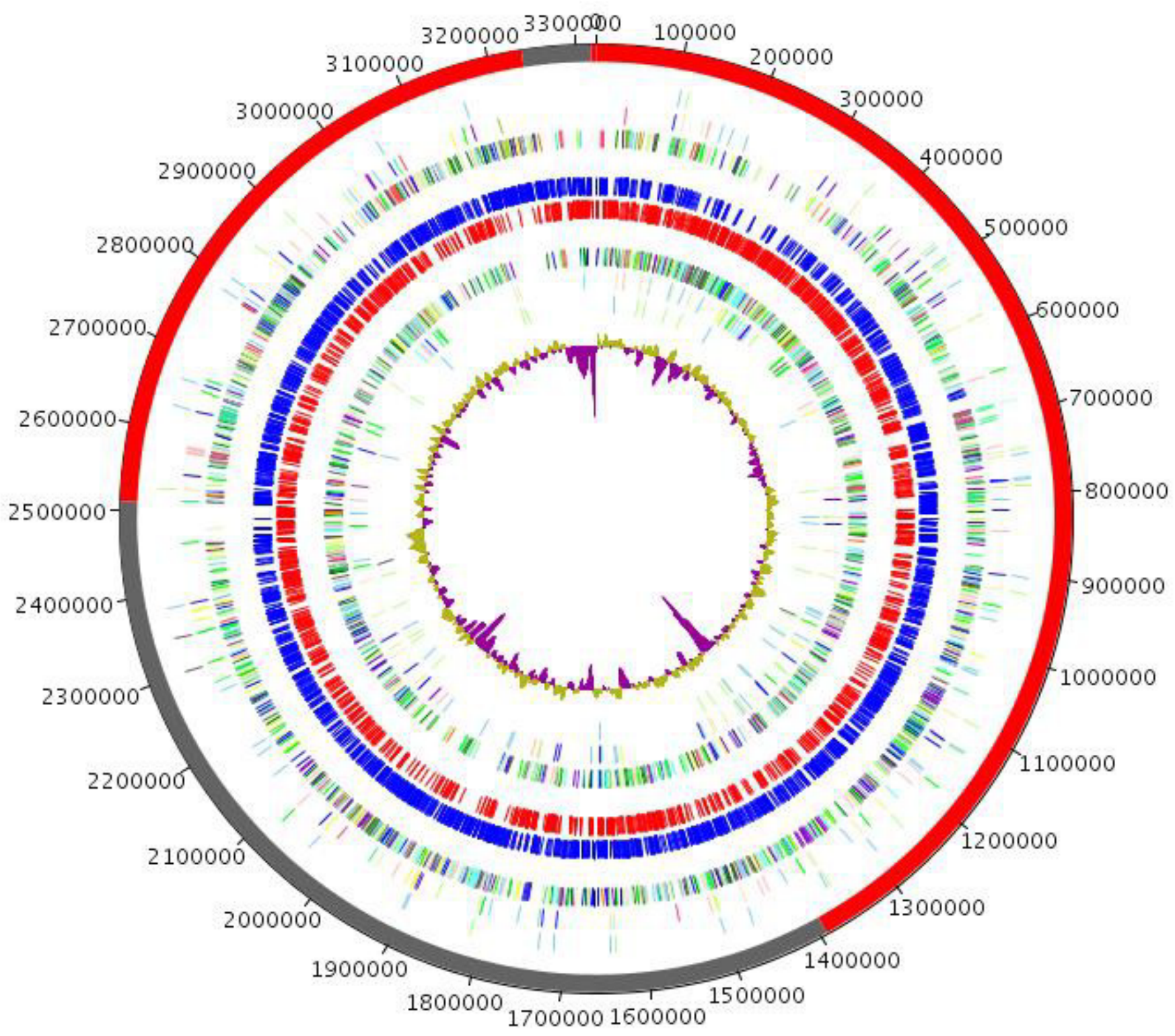

Figure 5. Graphical circular map of the C. massiliensis strain JC225 ${ }^{\top}$ genome. From outside to the center: scaffolds (red / grey), COG category of genes on the forward strand (three circles), genes on forward strand (blue circle), genes on the reverse strand (red circle), COG category on the reverse strand (three circles), G+C content. 
Table 4. Nucleotide content and gene count levels of the genome

\begin{tabular}{lrr}
\hline Attribute & Value & \% $_{\text {of total }}^{\mathbf{a}}$ \\
\hline Genome size (bp) & $3,407,283$ & 100 \\
DNA coding region (bp) & $3,091,035$ & 90.72 \\
DNA G+C content (bp) & $2,426,733$ & 71.22 \\
Total genes & 3,131 & 100 \\
RNA genes & 48 & 1.53 \\
Protein-coding genes & 3,083 & 98.47 \\
Genes with function prediction & 2,184 & 70.84 \\
Genes assigned to COGs & 2,155 & 69.9 \\
Genes with peptide signals & 387 & 12.55 \\
Genes with transmembrane helices & 721 & 23.39 \\
\hline
\end{tabular}

The total is based on either the size of the genome in base pairs or the total number of protein coding genes in the annotated genome.

Table 5. Number of genes associated with the 25 general COG functional categories

\begin{tabular}{crrl}
\hline Code & Value & \%age & Description \\
\hline J & 140 & 4.54 & Translation \\
A & 1 & 0.03 & RNA processing and modification \\
K & 225 & 7.3 & Transcription \\
L & 110 & 3.57 & Replication, recombination and repair \\
B & 1 & 0.03 & Chromatin structure and dynamics \\
D & 20 & 0.65 & Cell cycle control, mitosis and meiosis \\
Y & 0 & 0 & Nuclear structure \\
V & 27 & 0.88 & Defense mechanisms \\
T & 116 & 3.76 & Signal transduction mechanisms \\
M & 111 & 3.6 & Cell wall/membrane biogenesis \\
N & 42 & 1.36 & Cell motility \\
Z & 0 & 0 & Cytoskeleton \\
W & 1 & 0.03 & Extracellular structures \\
U & 41 & 1.33 & Intracellular trafficking and secretion \\
O & 82 & 2.66 & Posttranslational modification, protein turnover, chaperones \\
C & 132 & 4.28 & Energy production and conversion \\
G & 253 & 8.21 & Carbohydrate transport and metabolism \\
E & 276 & 8.95 & Amino acid transport and metabolism \\
F & 68 & 2.21 & Nucleotide transport and metabolism \\
H & 85 & 2.76 & Coenzyme transport and metabolism \\
I & 68 & 2.21 & Lipid transport and metabolism \\
P & 112 & 3.63 & Inorganic ion transport and metabolism \\
Q & 42 & 1.36 & Secondary metabolites biosynthesis, transport and catabolism \\
R & 323 & 10.48 & General function prediction only \\
S & 175 & 5.68 & Function unknown \\
- & 928 & 30.1 & Not in COGs \\
\hline & & &
\end{tabular}

The total is based on the total number of protein coding genes in the annotated genome. 


\section{Comparison with the genomes from other Cellulomonas species}

Here, we compared the genome sequence of $C$. massiliensis strain JC225 $5^{\mathrm{T}}$ with those of $C$. flavigena strain $134^{\mathrm{T}}$ [48] and C. fimi strain ATCC 484 (EMBL accession number CP002666). The draft genome sequence of $C$. massiliensis has a smaller size than those of $C$. flavigena and C. fimi (3.40 vs 4.12 and $4.26 \mathrm{Mb}$, respectively), a lower $\mathrm{G}+\mathrm{C}$ content (71.22 vs 74.3 and 74.7, respectively), and a smaller number of predicted genes $(3,131$ vs 3,788 and 3,863 , respectively). In addition, $C$. massiliensis shared a mean $88.75 \%$ (range 70.01 $100 \%$ ) and $89.61 \%$ (range $70.07-100 \%$ ) sequence similarity with $C$. flavigena and $C$. fimi, respectively, at the genome level.

\section{Conclusion}

On the basis of phenotypic, phylogenetic and genomic analyses, we formally propose the creation of Cellulomonas massiliensis sp. nov. that contains the strain JC225 ${ }^{\mathrm{T}}$. This bacterium has been found in Senegal.

\section{Description of Cellulomonas massiliensis sp. nov.} Cellulomonas massiliensis (ma.si.li.e'n.sis. L. gen. masc. n. massiliensis, of Massilia, the Latin name of Marseille where was isolated C. massiliensis).

Colonies are transparent and smooth with a diameter of $1 \mathrm{~mm}$ on blood-enriched Columbia agar and

\section{Acknowledgements}

The authors thank Mr. Julien Paganini at Xegen Company for automating the genomic annotation process.

\section{References}

1. Lagier JC, Armougom F, Million M, Hugon P, Pagnier I, Robert C, Bittar F, Fournous G, Gimenez G, Maraninchi M, et al. Microbial culturomics: paradigm shift in the human gut microbiome study. Clin Microbiol Infect 2012; 18:1185-1193. PubMed

2. Tindall BJ, Rossello-Mora R, Busse HJ, Ludwig W, Kämpfer P. Notes on the characterization of prokaryote strains for taxonomic purposes. Int I Syst Evol Microbiol 2010; 60:249-266. PubMed http://dx.doi.org/10.1099/ijs.0.016949-0

3. Genome Online Database. http://www.genomesonline.org/cgibin/GOLD/index.cgi

4. Welker M, Moore ER. Applications of whole-cell matrix-assisted laser-desorption/ionization time-
Brain Heart Infusion (BHI) agar. Cells are rodshaped with a diameter and length ranging from 0.37 to $0.60 \mu \mathrm{m}$ (mean of $0.48 \mu \mathrm{m}$ ), and from 0.55 to $1.4 \mu \mathrm{m}$ (mean of $0.95 \mu \mathrm{m}$ ), respectively. Optimal growth is achieved aerobically. Weak growth is observed with $5 \% \mathrm{CO}_{2}$ and under microaerophilic conditions. No growth is observed under anaerobic conditions. Growth occurs between $30-37^{\circ} \mathrm{C}$, with optimal growth at $37^{\circ} \mathrm{C}$. Cells stain Gram-positive, are non-endospore forming, and are motile. Catalase, oxidase, aesculin hydrolysis and $\beta$ galactosidase activities are present. Indole production, nitrate reduction, glucose fermentation, arginine dihydrolase, urease, gelatin hydrolysis, and glucose, arabinose, mannose, mannitol $\mathrm{N}$-acetylglucosamine, maltose, gluconate, caprate, adipate, malate, citrate, and phenyl-acetate assimilation activities are absent. Cells are susceptible to amoxicillin, imipenem, ciprofloxacin and gentamicin, but resistant to trimethoprim/sulfamethoxazole and metronidazole. The 16S rRNA and genome sequences are deposited in Genbank and EMBL under accession numbers JN657218 and CAHD00000000, respectively. The $\mathrm{G}+\mathrm{C}$ content of the genome is $71.22 \%$. The type strain JC225 ${ }^{\mathrm{T}}$ (= CSUR P160 = DSM 25695) was isolated from the fecal flora of a healthy patient in Senegal.

of-flight mass spectrometry in systematic microbiology. Syst Appl Microbiol 2011; 34:2-11. PubMed http://dx.doi.org/10.1016/j.syapm.2010.11.013

5. Lagier JC, El Karkouri K, Nguyen TT, Armougom F, Raoult D, Fournier PE. Non-contiguous finished genome sequence and description of Anaerococcus senegalensis sp. nov. Stand Genomic Sci 2012; 6:116-125. PubMed http://dx.doi.org/10.4056/sigs.2415480

6. Kokcha S, Mishra AK, Lagier JC, Million M, Leroy Q, Raoult D, Fournier PE. Non contiguousfinished genome sequence and description of $\mathrm{Ba}$ cillus timonensis sp. nov. Stand Genomic Sci 2012; 6:346-355. http://dx.doi.org/10.4056/sigs.2776064 
Cellulomonas massiliensis sp. nov.

7. Mishra AK, Gimenez G, Lagier JC, Robert C, Raoult D, Fournier PE. Non-contiguous finished genome sequence and description of Alistipes senegalensis sp. nov. Stand Genomic Sci 2012; 6:304-314. http://dx.doi.org/10.4056/sigs.2625821

8. Lagier JC, Armougom F, Mishra AK, Ngyuen TT, Raoult D, Fournier PE. Non-contiguous finished genome sequence and description of Alistipes timonensis sp. nov. Stand Genomic Sci 2012; 6:315-324. http://dx.doi.org/10.4056/sigs.2685917

9. Mishra AK, Lagier JC, Robert C, Raoult D, Fournier PE. Non-contiguous finished genome sequence and description of Clostridium senegalense sp. nov. Stand Genomic Sci 2012; 6:386-395.

10. Mishra AK, Lagier JC, Robert C, Raoult D, Fournier PE. Non-contiguous finished genome sequence and description of Peptoniphilus timonensis sp. nov. Stand Genomic Sci 2012; 7:111. http://dx.doi.org/10.4056/sigs.2956294

11. Mishra AK, Lagier JC, Rivet R, Raoult D, Fournier $P E$. Non-contiguous finished genome sequence and description of Paenibacillus senegalensis sp. nov. Stand Genomic Sci 2012; 7:70-81. http://dx.doi.org/10.4056/sigs.3054650

12. Bergey DH, Harrison FC, Breed RS, Hammer BW, Huntoon FM. In: Bergey DH, Harrison FC, Breed RS, Hammer BW, Huntoon FM (eds), Bergey's Manual of Determinative Bacteriology, First Edition, The Williams and Wilkins Co., Baltimore, 1923, p. 1-442.

13. Lee CM, Weon HY, Hong SB, Jeon YA, Schumann P, Kroppenstedt RM, Kwon SW, Stackebrandt E. Cellulomonas aerilata sp. nov., isolated from an air sample. Int / Syst Evol Microbiol 2008; 58:2925-2929. PubMed http://dx.doi.org/10.1099/ijs.0.2008/002253-0

14. Jones BE, Grant WD, Duckworth AW, Schumann P, Weiss N, Stackebrandt E. Cellulomonas bogoriensis sp. nov., an alkaliphilic cellulomonad. Int / Syst Evol Microbiol 2005; 55:1711-1714. PubMed http://dx.doi.org/10.1099/ijs.0.63646-0

15. Shi Z, Luo G, Wang G. Cellulomonas carbonis sp. nov., isolated from coal mine soil. Int J Syst Evol Microbiol 2012; 62:2004-2010. PubMed http://dx.doi.org/10.1099/ijs.0.034934-0

16. Yoon MH, Ten LN, Im WT, Lee ST. Cellulomonas chitinilytica sp. nov., a chitinolytic bacterium isolated from cattle-farm compost. Int I Syst Evol
Microbiol 2008; 58:1878-1884. PubMed

http://dx.doi.org/10.1099/ijs.0.64768-0

17. Kang MS, Im WT, Jung HM, Kim MK, Goodfellow M, Kim KK, Yang HC, An DS, Lee ST.

Cellulomonas composti sp. nov., a cellulolytic bacterium isolated from cattle farm compost. Int J Syst Evol Microbiol 2007; 57:1256-1260. PubMed http://dx.doi.org/10.1099/ijs.0.63974-0

18. Brown JM, Frazier RP, Morey RE, Steigerwalt AG, Pellegrini GJ, Daneshvar MI, Hollis DG, McNeil MM. Phenotypic and genetic characterization of clinical isolates of CDC coryneform group A-3: proposal of a new species of Cellulomonas, Cellulomonas denverensis sp. nov. J Clin Microbiol 2005; 43:1732-1737. PubMed http://dx.doi.org/10.1128/JCM.43.4.1732$\underline{1737.2005}$

19. Funke $G$, Ramos CP, Collins MD. Identification of some clinical strains of CDC coryneform group A3 and A-4 bacteria as Cellulomonas species and proposal of Cellulomonas hominis sp. nov. for some group A-3 strains. J Clin Microbiol 1995; 33:2091-2097. PubMed

20. Collins MD, Pascual C. Reclassification of Actinomyces humiferus (Gledhill and Casida) as Cellulomonas humilata nom. corrig., comb. nov. Int J Syst Evol Microbiol 2000; 50:661-663. PubMed http://dx.doi.org/10.1099/00207713-50-2$\underline{661}$

21. Elberson MA, Malekzadeh F, Yazdi MT, Kameranpour N, Noori-Daloii MR, Matte MH, Shahamat M, Colwell RR, Sowers KR. Cellulomonas persica sp. nov. and Cellulomonas iranensis sp. nov., mesophilic cellulose-degrading bacteria isolated from forest soils. Int / Syst Evol Microbiol 2000; 50:993-996. PubMed http://dx.doi.org/10.1099/00207713-50-3-993

22. Rusznyák A, Toth EM, Schumann $P$, Sproer $C$, Makk J, Szabo G, Vladar P, Marialigeti K, Borsodi AK. Cellulomonas phragmiteti sp. nov., a cellulolytic bacterium isolated from reed (Phragmites australis) periphyton in a shallow soda pond. Int J Syst Evol Microbiol 2011; 61:1662-1666. PubMed http://dx.doi.org/10.1099/ijs.0.022608-0

23. An DS, Im WT, Yang HC, Kang MS, Kim KK, Jin L, Kim MK, Lee ST. Cellulomonas terrae sp. nov., a cellulolytic and xylanolytic bacterium isolated from soil. Int / Syst Evol Microbiol 2005; 55:17051709. PubMed http://dx.doi.org/10.1099/ijs.0.63696-0

24. Rivas R, Trujillo ME, Mateos PF, Martinez-Molina E, Velazquez E. Cellulomonas xylanilytica sp. 
nov., a cellulolytic and xylanolytic bacterium isolated from a decayed elm tree. Int / Syst Evol Microbiol 2004; 54:533-536. PubMed http://dx.doi.org/10.1099/ijs.0.02866-0

25. Lai PC, Chen YS, Lee SS. Infective endocarditis and osteomyelitis caused by Cellulomonas: a case report and review of the literature. Diagn Microbiol Infect Dis 2009; 65:184-187. PubMed http://dx.doi.org/10.1016/j.diagmicrobio.2009.06. $\underline{001}$

26. Sharma S, Saffra NA, Chinyadza T, Ghitan M, Chapnick EK. Endocapsular cellulomonas as a cause of persistent postoperative endophthalmitis. Ophthalmic Surg Lasers Imaging 2008; 39:328330. PubMed http://dx.doi.org/10.3928/15428877-2008070116

27. Ohtaki H, Ohkusu K, Sawamura H, Ohta H, Inoue R, Iwasa J, Ito H, Murakami N, Ezaki T, Moriwaki H, Seishima M. First report of acute cholecystitis with sepsis caused by Cellulomonas denverensis. J Clin Microbiol 2009; 47:33913393. PubMed http://dx.doi.org/10.1128/JCM.00678-09

28. Trape JF, Tall A, Diagne N, Ndiath O, Ly AB, Faye J, Dieye-Ba F, Roucher C, Bouganali C, Badiane A, et al. Malaria morbidity and pyrethroid resistance after the introduction of insecticide-treated bednets and artemisinin-based combination therapies: a longitudinal study. Lancet Infect Dis 2011; 11:925-932. PubMed http://dx.doi.org/10.1016/S1473-3099(11)70194$\underline{3}$

29. Woese CR, Kandler O, Wheelis ML. Towards a natural system of organisms: proposal for the domains Archaea, Bacteria, and Eucarya. Proc Natl Acad Sci USA 1990; 87:4576-4579. PubMed http://dx.doi.org/10.1073/pnas.87.12.4576

30. Garrity GM, Holt JG. The Road Map to the Manual. In: Garrity GM, Boone DR, Castenholz RW (eds), Bergey's Manual of Systematic Bacteriology, Second Edition, Volume 1, Springer, New York, 2001, p. 119-169.

31. Stackebrandt E, Ebers J, Rainey F, Ward-Rainey N. Proposal for a New Hierarchic Classification System, Actinobacteria classis nov. Int J Syst Bacteriol 1997; 47:479-491. http://dx.doi.org/10.1099/00207713-47-2-479

32. Skerman V, McGowan V, Sneath P. Approved Lists of Bacterial Names. Int J Syst Bacteriol 1980; 30:225-420. http://dx.doi.org/10.1099/00207713$\underline{30-1-225}$
33. Buchanan RE. Studies in the nomenclature and classification of bacteria. II. The primary subdivisions of the Schizomycetes. J Bacteriol 1917; 2:155-164. PubMed

34. Zhi XY, Li WJ, Stackebrandt E. An update of the structure and 16S rRNA gene sequence-based definition of higher ranks of the class Actinobacteria, with the proposal of two new suborders and four new families and emended descriptions of the existing higher taxa. Int I Syst Evol Microbiol 2009; 59:589-608. PubMed http://dx.doi.org/10.1099/ijs.0.65780-0

35. Stackebrandt E, Prauser H. Assignment of the genera Cellulomonas, Oerskovia, Promicromonospora, and Jonesia to Cellulomonadaceae fam. nov. Syst Appl Microbiol 1991; 14:261-265. http://dx.doi.org/10.1016/S0723-2020(11)80378$\underline{4}$

36. List Editor. Validation of the publication of new names and new combinations previously effectively published outside the IJSB. List no. 39. Int J Syst Bacteriol 1991; 41:580-581. PubMed http://dx.doi.org/10.1099/00207713-41-4-580

37. Stackebrandt E, Schumann P. Description of Bogoriellaceae fam. nov., Dermacoccaceae fam. nov., Rarobacteraceae fam. nov. and Sanguibacteraceae fam. nov. and emendation of some families of the suborder Micrococcineae. Int J Syst Evol Microbiol 2000; 50:1279-1285. PubMed http://dx.doi.org/10.1099/00207713-50-3$\underline{1279}$

38. Ashburner M, Ball CA, Blake JA, Botstein D, Butler $\mathrm{H}$, Cherry JM, Davis AP, Dolinski K, Dwight SS, Eppig JT, et al. Gene ontology: tool for the unification of biology. The Gene Ontology Consortium. Nat Genet 2000; 25:25-29. PubMed http://dx.doi.org/10.1038/75556

39. Stackebrandt E, Ebers J. Taxonomic parameters revisited: tarnished gold standards. Microbiol TOday 2006; 33:152-155.

40. GenBank database. http://www.ncbi.nlm.nih.gov/genbank

41. Seng P, Drancourt M, Gouriet F, La Scola B, Fournier PE, Rolain JM, Raoult D. Ongoing revolution in bacteriology: routine identification of bacteria by matrix-assisted laser desorption ionization time-of-flight mass spectrometry. Clin Infect Dis 2009; 49:543-551. PubMed http://dx.doi.org/10.1086/600885

42. Field D, Garrity G, Gray T, Morrison N, Selengut J, Sterk P, Tatusova T, Thomson N, Allen MJ, 
Angiuoli SV, et al. The minimum information about a genome sequence (MIGS) specification. Nat Biotechnol 2008; 26:541-547. PubMed http://dx.doi.org/10.1038/nbt1360

43. Prodigal. http://prodigal.ornl.gov

44. Lowe TM, Eddy SR. tRNAscan-SE: a program for improved detection of transfer RNA genes in genomic sequence. Nucleic Acids Res 1997;

25:955-964. PubMed

45. Lagesen K, Hallin P, Rodland EA, Staerfeldt HH, Rognes T, Ussery DW. RNAmmer: consistent and rapid annotation of ribosomal RNA genes. Nucleic Acids Res 2007; 35:3100-3108. PubMed http://dx.doi.org/10.1093/nar/gkm160

46. Krogh A, Larsson B. von HG, Sonnhammer EL. Predicting transmembrane protein topology with a hidden Markov model: application to complete genomes. J Mol Biol 2001; 305:567-580. PubMed http://dx.doi.org/10.1006/jmbi.2000.4315

47. Bendtsen JD, Nielsen H. von HG, Brunak S. Improved prediction of signal peptides: SignalP 3.0. J Mol Biol 2004; 340:783-795. PubMed http://dx.doi.org/10.1016/j.jmb.2004.05.028

48. Abt B, Foster B, Lapidus A, Clum A, Sun H, Pukall R, Lucas S, Glavina Del Rio T, Nolan M, Tice H, et al. Complete genome sequence of Cellulomonas flavigena type strain $\left(134^{\top}\right)$. Stand Genomic Sci 2010; 3:15-25. PubMed http://dx.doi.org/10.4056/sigs.1012662

49. Cavalier-Smith T. The neomuran origin of archaebacteria, the negibacterial root of the universal tree and bacterial megaclassification. Int J Syst Evol Microbiol 2002; 52:7-76. PubMed 